\title{
Reform Program Analysis on Improving the Quality of Personnel Training

\author{
Ping Xin ${ }^{1, a}$, Jian Xue ${ }^{1, b^{*}}$ and Dejun Liu, ${ }^{1, c}$ \\ ${ }^{1}$ BeiHua University, Jilin City Longtan Hill Street No. 1, JiLin, China \\ a359411897@qq.com, b11496332@qq.com, c14145277@qq.com
}

${ }^{*}$ The corresponding author

Keywords: Personnel training; Undergraduate teaching quality improvement; Reform in teaching methods; Practice teaching; Teaching quality guarantee system

\begin{abstract}
To adapt to local and industrial economic construction oriented, deepen teaching reform, strengthen the construction of teachers and improve teaching management, explore and construct a new teaching system with characteristics. Efforts to cultivate faith persistence, moral excellence, knowledge rich, competent high-quality innovative talents, improve personnel training, scientific research, social services, cultural heritage innovation level. On the basis of orientation and training objectives, strengthen professional construction, curriculum construction and teaching staff construction, adjusting training plan and optimize the curriculum system, reforming teaching methods, strengthening practice teaching, strengthen the training of innovation ability, improve the quality of teaching.
\end{abstract}

\section{General Ideas and Policy Measures of Teaching Reform}

Teaching is the prerequisite and basis for educational reform, in order to meet the needs of the development of science and technology and education, college carry out the "renew education ideas, improve the quality of personnel training seminar, make every teacher who is passive teaching reform become a standard bearer[1,2]. To strengthen the professional construction, curriculum construction and teaching staff construction, adjusting training plan and optimize the curriculum system, reforming teaching methods, strengthening practice teaching, strengthen the training of innovation ability, improve teaching quality monitoring and evaluation system, improve the quality of teaching.

The implementation of "a group of diversity, innovative practice" innovative talent model, promote the "undergraduate teaching quality improvement project" implementation[3]. The development of teaching reform of incentive policy, as an important part of teaching reform, teaching teachers, excellent teachers selection and other activities, to obtain the achievements of teaching reform of teachers in the evaluation, training, evaluation and so on[4,5]. Through the investigation to obtain information on enterprise personnel training requirements, adjust personnel training programs, reform personnel training model, the establishment of application-oriented engineering and technical personnel model. Through the development of the second classroom and innovative quality development and turn professional to build a personalized development of talent model.

\section{Teaching Methods and Learning Styles}

Teachers in the teaching process, strict accordance with the syllabus for the selection of teaching materials, assessment, performance evaluation and teaching content. Each professional to achieve training specifications and requirements, set up different ability training module. That is, humanities, ideological and moral ability module, basic skills training module, comprehensive ability, scientific research ability training module and innovation entrepreneurial ability training module. Teaching content closely follow the technical development, engineering projects and research results into the classroom in a timely manner, reflecting scientific research to promote teaching.

In the teaching of a teacher led, student-centered concept; change the one-way knowledge of classroom teaching mode for two-way or multiple communication, changed into teaching way for the heuristic and discuss teaching mode method and examples、 the classroom lectures and discussion. 
Students learn to combine the knowledge of debris. It can fully mobilize the enthusiasm of students and encourage students' personality development.

Taking the combination of teaching methods inside and outside and carrying out case teaching that can stimulate learning enthusiasm. The operation of a strong curriculum to the laboratory teaching, take the way to do high school. The use of information, three-dimensional and other diverse means of teaching and the construction of online courses and so on are adapted[6].

The students' learning initiative was stimulated through outstanding student learning exchange, exchange of experience, review postgraduate entrance examination scores. Relying on internal and external practice of College Students' innovation and entrepreneurship education base, the comprehensive design of teachers in scientific research[7], enterprise development projects, all levels of innovation and entrepreneurship training programs, various academic competitions, open experiment, the second classroom social practice, such as the carrier, in order to "interest driven, independent practice, focusing on the process" as the basic principle, the way of learning by teaching to independence, by inheritance to innovation, learning state by blind type to independent type, from examination to interest.

\section{Practice Teaching}

Based on the consideration of students, professional requirements, interests, expertise and ability to play the differences, build basic, comprehensive design, engineering and innovative "experimental curriculum as a whole system of multi-level, three-dimensional, open type, as shown in Table 1.

Optimization of the experimental teaching contents, improving teaching methods and teaching means, pay attention to the cultivation of students' experimental skills and ability of design and application, improve the comprehensive and designing experimental project scale. The use of modern technology to implement the traditional teaching method, adopt the combination of theory teaching and practice teaching, the application of strong theory course to the laboratory, to achieve edge while training, "doing" effect[8,9]. The theoretical and experimental courses in the same important position, part of the experimental class independent courses, separate examinations. Outstanding students are the main process of experimental teaching, training students' experimental ability, research and innovation ability[10].

Table 1 High and low settings of predictor variables

\begin{tabular}{|c|c|c|c|}
\hline The three level & The six module & Training goal & Teaching link \\
\hline \multirow{2}{*}{$\begin{array}{l}\text { Basic practice } \\
\text { layer }\end{array}$} & $\begin{array}{l}\text { Thought quality } \\
\text { module }\end{array}$ & $\begin{array}{l}\text { Cultivate ideological and moral } \\
\text { qualities, physical and mental } \\
\text { development, human quality }\end{array}$ & \multirow{2}{*}{$\begin{array}{l}\text { Experiment, } \\
\text { computer, social } \\
\text { investigation, military } \\
\text { training, labor, basic } \\
\text { manufacturing } \\
\text { process practice }\end{array}$} \\
\hline & Basic skills module & $\begin{array}{l}\text { Cultivate basic practical ability and } \\
\text { basic skills, establish practical } \\
\text { awareness }\end{array}$ & \\
\hline \multirow{2}{*}{$\begin{array}{l}\text { Professional } \\
\text { practice layer }\end{array}$} & $\begin{array}{l}\text { Professional } \\
\text { design module }\end{array}$ & $\begin{array}{l}\text { Cultivating professional practice } \\
\text { ability and professional skills, forming } \\
\text { students practical accomplishment }\end{array}$ & \multirow{2}{*}{$\begin{array}{l}\text { Curriculum design, } \\
\text { professional practice, } \\
\text { production practice, } \\
\text { laboratory opening }\end{array}$} \\
\hline & $\begin{array}{l}\text { Interdisciplinary } \\
\text { module }\end{array}$ & $\begin{array}{l}\text { To expand knowledge, adapt to the } \\
\text { needs of individual }\end{array}$ & \\
\hline \multirow{2}{*}{$\begin{array}{l}\text { Comprehensive } \\
\text { practice layer }\end{array}$} & $\begin{array}{l}\text { Comprehensive } \\
\text { skills module }\end{array}$ & $\begin{array}{l}\text { Cultivating comprehensive ability, } \\
\text { scientific research ability and } \\
\text { comprehensive application ability }\end{array}$ & \multirow{2}{*}{$\begin{array}{l}\text { Graduation practice, } \\
\text { graduation design, } \\
\text { quality development } \\
\text { credit, subject } \\
\text { competition, } \\
\text { innovation }\end{array}$} \\
\hline & $\begin{array}{l}\text { New business } \\
\text { module }\end{array}$ & $\begin{array}{l}\text { Cultivate innovation spirit, improve } \\
\text { comprehensive quality and innovation } \\
\text { practice ability }\end{array}$ & \\
\hline
\end{tabular}


To formulate measures for the administration of open laboratory management, open systems and the administration of the use of open funds. Participate in the open guidance teacher to give the workload of open laboratory fees, students reach a certain period, those who pass the examination for the innovative credits, to open laboratory do good teachers and laboratory technicians to reward. Design for training student's comprehensive ability, and innovation ability, the professional constantly reduce the verification experiment, increase the comprehensive and designing experimental project, Institute of laboratory equipment maintenance in a timely manner to ensure supplies ready, the experiment out rate of $100 \%$. Develop research laboratories open management approach to undergraduate students, clearly defined engineering centers, research institutes must be open to undergraduates. The combination of teachers' scientific research center and research content, absorbed some excellent undergraduate students into the center, Research Institute of Teachers Participation in research activities; the completion of college students apply for innovative projects and small production, small inventions can center, study the use conditions.

\section{Teaching Quality Assurance System}

Focus on personnel training objectives, combined with the actual school, basic requirements, establish and perfect the theoretical teaching and practical teaching of the main parts of the quality standards and assessment methods, formulate relevant quality standard file system. The quality standard of teaching in the aspects of the implementation of normalization in the teaching process based on the school supervision lectures, take college professional steering group lectures, peer review of teaching, students' evaluation of teaching and a series of supervision and feedback mechanism, to ensure the teaching effect. The teaching quality monitoring process is shown in Fig. 1.

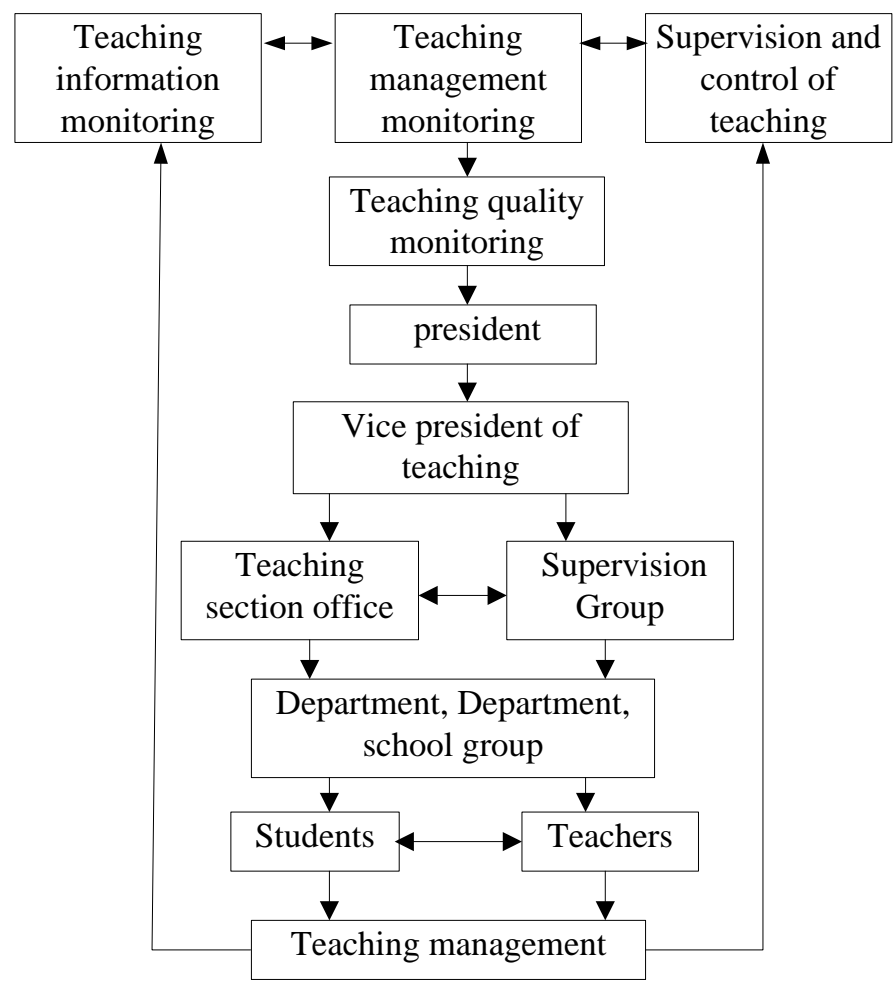

Figure 1. Teaching quality monitoring process

Establish education oriented, students are the main body to enhance the quality of personnel training for the purpose of reform as a means to strengthen the connotation of construction. College teaching quality assurance mode consists of four subsystems, namely, quality target and standard system, teaching organization and implementation system, teaching process monitoring system, teaching quality information collection and feedback system. 
College teaching quality assurance mode consists of four subsystems, namely, quality target and standard system, teaching organization and implementation system, teaching process monitoring system, teaching quality information collection and feedback system.

Quality objectives and standards system: according to the talent quality target system (Amendment) order of professional talent training standards and professional personnel training plan, teaching quality standard, students' learning quality standards, the quality of teaching management standards and teaching quality of service standards.

Teaching organization and implementation system: the implementation of quality standards, the implementation of professional training programs, the use of teaching resources, organize the implementation of various teaching activities. Carry out quality engineering construction, carry out teaching reform and teaching research activities, conduct laboratory and practice base construction. Organize course examination, graduation qualification examination, management of teaching documents.

Teaching process monitoring system: the implementation of quality standards, deployment of teaching resources, control of teaching operations, the implementation of supervision, inspection, evaluation of teaching, curriculum examination, job evaluation and other quality control.

The quality of teaching information collection and feedback system: collect feedback information including teaching quality, teaching supervision information, leadership and peer class information, student information information, graduates information, employer information, timely correction of teaching activities.

\section{Conclusion}

Research conforms to the inevitable trend of the development of education in the era of internet technology, to solve the current higher education with guidance and reference to some problems, has certain theoretical value and practical value to improve the quality of education and promote the reform of higher education personnel training.

Adhere to the "scientific research to promote teaching, practice to promote innovation, promote the development of the characteristics of" teaching ideas. While strengthening the basic knowledge of student discipline, pay attention to the cultivation of students' engineering application ability, pay attention to the cultivation of students' academic frontier quality.

\section{Acknowledgements}

This work was supported by the Education Department Project of Jilin Province: (Education Department of Jilin Province [2016]32nd); The Education Department of the Ministry of education higher education professional teaching steer, Project approval number[DQJZW2016002]; Education and teaching research topics of Beihua University [BHDQ31]

\section{References}

[1] Y.Z. Gong. On the Training Mode of University Talents (JiangSu Education Press, China 1999, P.36). (In Chinese)

[2] K.N. Wu: Higher Education Research is needed for Innovative Talents Training, Vol. 1 (2013) No.3, p.30. (In Chinese)

[3] R.Petrova, A.Tibrewal, T.M. Sobh: Journal of STEM Education, Vol.7, (2006) No3, p.44.

[4] A.J. Basim, A.A. Hazim: European Journal of Engineering Education, Vol.5, (2010) No2, p.489.

[5] Z.J. Wu, J.Q. Li: Higher Engineering Education Research, Vol. 15, (2013) No5, p.56. (In Chinese)

[6] [6] F.M. Kong: such as the construction of road of the applied university (Peking University press, China 2006). (In Chinese) 
[7] J.Lin: Higher Engineering Education and Research, Vol.3, (2010) No1, p.35. (In Chinese)

[8] Y.G. Hong, D.Z. Cheng. Generation Exhibition, Analysis and Control of Nonlinear system(Science Press, China 2005). (In Chinese)

[9] Y.M. Sun, L. Guo: Chinese Science, Vol.35, (2005) No8, p.830. (In Chinese)

[10]D.Z. Cheng: IEEE Trans. on Automatic Control, Vol.50, (2005) No4, p.511. (In Chinese) 